\title{
Raw and cooked meat emulsion stability as affected by starches determined by principal component analysis
}

\author{
Octavio Toledo, Alfonso Totosaus* \\ Food Science Lab and Pilot Plant, Tecnológico Estudios Superiores Ecatepec. Av. Tecnologico esq. Av. Central s/n, Ecatepec 55210, Estado \\ de México, México
}

\section{A B S T R A C T}

\begin{abstract}
This work aimed to study the relationship between meat emulsion in both raw and cooked states employing two different types of starch, potato, and wheat, in meat batters formulated with different fat percent. Emulsion stability as related to water retention capacity, thermal denaturation temperature, and enthalpy plus thermal diffusivity were determined in the raw and cooked state. There was an inherent difference in potato starch functionality, with higher emulsion stability and yield, but the Pearson correlation analysis and PCA demonstrated that water holding capacity and the denaturation enthalpy resulted in higher cook yield as a consequence of lower expressible moisture. This results in establishing the importance to maintain meat extensors as starches functionality before and during mixing and thermal processing to obtain better yield and less water release in fat-reduced meat products, both important quality parameters, related to sensory (juiciness) and texture (hardness) properties of comminuted meat products.
\end{abstract}

Keywords: meat batters; water holding capacit; DSC; thermal diffusivity; starch

\section{INTRODUCTION}

In emulsified cooked meat products water has an important role being part of the continuous phase of salt-solubilized proteins of the meat emulsion that retains fat and moisture before, during, and after thermal treatment to form the meat protein gel matrix, responsible for final product quality (texture and juiciness). The capacity of meat batter emulsion to retain fat and water in the processing is reflected in the emulsion stability that indicates the properties of hydration and binding, i.e., avoid fat and collagen separation (Aktas and Gençelep, 206). In this view, starches as fillers primarily increased yields, but also may make significant contributions to the stability and textural firmness of wieners (Comer et al., 1986). The composite reinforcing effect of starch may be due to the swelling of starch granules embedded in the protein gel, which compresses the matrix, and that the protein matrix loses moisture and starch added in meat emulsions favors the formation of a more compact and stronger heat-induced protein network (Li and Yeh, 2001).

The effects of starch on batters were influenced by the starch type, water-to starch ratio, presence of other compounds (such as lipids), and processing factors (Dexter et al., 1993). Starch gelatinization comprises the dispersed starch granules swelling in water during the cooking process, resulting in a gel structure, since sausages cooking temperature is enough to allow the gelatinization in stables and homogenous starch granules (Comer, 1989). Cooking loss decreased due to the swelling power of starch, since meat proteins denaturation started before starch gelatinization temperature, with no chemical interaction between meat proteins and starch $(\mathrm{Li}$ and $\mathrm{Yeh}$, 2003). The use of starch in the formulation of meat products implies the final texture and mouthfeel as key quality attributes, obtaining a standard composition related to water level and fat content as a result of starch functionality, reflected in expected yield and purge control at a lower cost, improving shelf-life conditions during storage (Joly and Anderstein, 2009).

Previous researches describe the concomitant effect of different botanical origin starches, but without establishing a relationship among the different starches properties in the raw meat batter competing for water with myofibrillar proteins, during the thermal processing where meat proteins gelification and starches swelling occurs, and in the cold gelled meat batter. The objective of this work was to determine the relationship between both thermal and

\footnotetext{
Corresponding author:

Alfonso Totosaus, Food Science Lab \& Pilot Plant, Tecnológico Estudios Superiores Ecatepec. Av. Tecnologico esq. Av. Central s/n, Ecatepec 55210, Estado de México, México. E-mail: atotosaus@tese.eu.mx
} 
emulsion meat batter stability with two types of starches, potato, and wheat, at different concentrations of fat, before and after the thermal process.

\section{MATERIALS AND METHODS}

\section{Meat batters and fat replacers elaboration}

Mechanically deboned poultry (Grupo Pecuario San Antonio, México) $(55 \% \mathrm{w} / \mathrm{w})$ was mixed with salt $(2.50 \%$ w/w), commercial phosphate mixture (FABPSA, México City, $0.40 \% \mathrm{w} / \mathrm{w})$ and curing salt $(0.15 \% \mathrm{w} / \mathrm{w})$ with half of the total ice during two min in a Chef Prep 70610 Food Processor (Hamilton Beach, Glen Allen). Frozen lard $(20,15$, or $10 \%)$ was added and emulsified for two more minutes. The rest of the ice was added and emulsified during 2-3 min, adding potato or wheat starch (5.0, 7.5 or $10.0 \% \mathrm{w} / \mathrm{w}$ ) until total ingredient incorporation, maintain batter temperature at $12 \pm 2{ }^{\circ} \mathrm{C}$. Batters were stuffed into 20-mm diameter cellulose casing and cooked in a water bath until reaching an internal temperature of $70 \pm 2{ }^{\circ} \mathrm{C}$ (about $15 \mathrm{~min}$ ), cooled in an ice bath, and vacuum-packed and stored at $4{ }^{\circ} \mathrm{C}$ until subsequent analysis. A total of three batches of one kilo for each one of the treatments were manufactured with the same ingredients, formulation and, technology in two different days.

\section{Raw batters' properties}

Batter water-holding capacity, as the ability of the uncooked product to retain moisture, was adapted from Hughes et al. (1996). $10 \mathrm{~g}$ of the raw meat batter sample was placed in a $50 \mathrm{~mL}$ centrifuge tube, wrapped in cotton cheesecloth, and centrifuged for $10 \mathrm{~min}$ at $3,000 \times \mathrm{g}$. The cheesecloth was removed, and the sample weight was measured again. The water holding capacity (WHC) was calculated as:

$$
\text { WHC }(\%)=1-\frac{\text { Fluids loss after centrifugation }}{\text { Total water content }} \times 100
$$

Raw emulsion stability, as the total expressible fluid (Hughes et al., 1996), was determined centrifuged raw emulsion $(25 \pm 1 \mathrm{~g})$ for $5 \mathrm{~min}$ at $3,000 \times \mathrm{g}$. The pelleted samples were removed and weighed, and the supernatants were poured into pre-weighed bakers and dried overnight at $100{ }^{\circ} \mathrm{C}$ to report total expressible fluids (TEF) estimated as:

$$
\text { Total expressible fluid }(\%)=\frac{\begin{array}{l}
\text { Weight of dried } \\
\text { supernatant }
\end{array}}{\text { Sample weight }} \times 100
$$

Cook stability was determined according to the methodology reported by Haq et al. (1972). 30g of the uncooked emulsion was placed in a $50 \mathrm{~mL}$ centrifuge tube and cook for $30 \mathrm{~min}$ in a $70^{\circ} \mathrm{C}$ water bath. The cook stability was calculated according to:

$$
\text { Cook stability }(\%)=\frac{\text { Cooked sample weight }}{\text { Uncooked sample weight }} \times 100
$$

The thermal properties were determined in a Mettler DSC1 differential scanning calorimeter (Mettler Toledo, Columbus, USA), calibrated with indium and nitrogen flow purge $(20 \mathrm{~mL} / \mathrm{min})$, employing an empty pan as reference. Previously liquid nitrogen lyophilized raw meat batters' samples were weighted $(0.012 \pm 0.002 \mathrm{~g})$ in $40 \mu \mathrm{L}$ crucibles aluminum pans and sealed. The scanning temperature was increased from 30 to $275^{\circ} \mathrm{C}$ at $10{ }^{\circ} \mathrm{C} / \mathrm{min}$. The peak temperature (thermal denaturation temperature, $\mathrm{Td}$ ), and heat of phase transition (thermal denaturation enthalpy, $\Delta \mathrm{H}$ ) were determined in the respective thermogram ( $\mathrm{Li}$ and Yeh, 2002).

Thermal diffusivity was determined according to the reported by Markowski et al. (2004), employing J-type thermocouples accoupled to an Extech EasyViewTM15 thermocouple (Extech Instruments Corporation, Waltham, USA) used to determine the time history of sample temperatures during cooking and cooling. One thermocouple placed along the cylinder radius and fixed near the geometric center of the sample, the tip of another one was placed just under the sample surface. Another thermocouple was placed into water, stirred neither during cooking nor during cooling, to determine the process temperature $\left(95^{\circ} \mathrm{C}\right)$. When the temperature at the central point of the sample (Tc) increased to $75^{\circ} \mathrm{C}$, the sample was taken out of hot water and transferred to an ice bath until the central point temperature decreased to $40{ }^{\circ} \mathrm{C}$, monitoring temperature changes sample center and on the sample surface, and water bath. Based on the conduction heat transfer equation with a constant sample surface temperature (Ts), the temperature of a water bath during cooking and cooling was assumed to be constant, and constant heat diffusivity during cooking and cooling for a cylinder (with a length $2 \mathrm{~L}$ ) and a radius $(\mathrm{R})$, linearly time-dependent, with a slope (B) of the plot of $\ln (\mathrm{Ts}-\mathrm{Tc})$ versus time, to calculate thermal diffusivity as:

$$
\alpha=B\left[\left(\frac{2.405}{\mathrm{R}}\right)^{2}+\left(\frac{2 \pi}{L}\right)^{2}\right]^{-1}
$$

\section{Cooked batters' properties}

After the batters were cooked and stored under refrigeration $\left(6 \pm 2{ }^{\circ} \mathrm{C}\right)$ during $24 \mathrm{~h}$, the product was reweighed, and the cooking yield was calculated based on the raw product weight (Shand, 2000). 
Moisture content was quantified using AOAC Official Test Method No. 950.46 (1999). Two g samples were placed in an aluminum capsule at a constant weight and heated in an oven at $110^{\circ} \mathrm{C}$ for $12 \mathrm{~h}$. The samples were then removed, and the percentage of moisture was calculated based on weight difference.

Expressible moisture was determined by the methodology reported by Jauregui et al. (1981). Three pieces of Whatman \#4 filter paper were weighted, folded into a thimble shape with $2 \pm 0.3 \mathrm{~g}$ of ground meat batter sample and centrifuged at $3,000 \times \mathrm{g}$ for $20 \mathrm{~min}$ at $4^{\circ} \mathrm{C}$. Expressible moisture was reported as the percentage of weight loss from the original weight of the sample.

The thermal properties were determined in a Mettler DSC1 differential scanning calorimeter (Mettler Toledo, Columbus, USA), calibrated with indium and nitrogen flow purge $(20 \mathrm{~mL} / \mathrm{min})$, employing an empty pan as reference. Previously liquid nitrogen lyophilized cooked sausage samples were weighted $(0.012 \pm 0.002 \mathrm{~g})$ in $40 \mu \mathrm{L}$ crucibles aluminum pans and sealed. The scanning temperature was increased from 30 to $275^{\circ} \mathrm{C}$ at $10{ }^{\circ} \mathrm{C} / \mathrm{min}$. The peak temperature (thermal denaturation temperature, $\mathrm{Td}$ ), and heat of phase transition (thermal denaturation enthalpy, $\Delta \mathrm{H})$ were determined in the respective thermogram ( $\mathrm{Li}$ and Yeh, 2002).

\section{Experimental design and data analysis}

To determine the effect of different type (potato or wheat) starch and starch content $(5.0,7.5$ or $10 \%)$ on fat reduced $(10,15$ or $20 \%)$ mechanically deboned meat batters, the proposed model was:

$$
\mathrm{y}_{\mathrm{ijk}}=\mu+\alpha_{\mathrm{i}}+\beta_{\mathrm{j}}+\gamma_{\mathrm{k}}+\varepsilon_{\mathrm{ijk}}
$$

Where $\mathrm{y}_{\mathrm{ijk}}$ represents the thermal and moisture properties for the ith starch type at the jth starch content at the kth fat percent; $\alpha \mathrm{i}, \beta \mathrm{j}$ and $\gamma \mathrm{k}$ are the main effects of starch type, starch content and fat percent; eijk represents the residual error terms, assumed to be normally distributed, with zero mean and variance $\sigma 2$ (Der and Everitt, 2008). Data analysis was carried out using SAS statistical software v. 9.3 (SAS Institute, Cary) with the PROC ANOVA procedure. The significant difference among means was determined by Duncan's means test $(\mathrm{P}=0.05)$ in the same software.

The relations between raw meat batters' properties (raw cook stability, water holding capacity, total expressible moisture, raw $\mathrm{Td}$, raw $\Delta \mathrm{H}$, and thermal diffusivity) and cooked meat batters' properties (total moisture, cooking yield, expressible moisture, cooked $\mathrm{Td}$ and cooked $\Delta \mathrm{H}$ ) was determined by correlation analysis and principal component analysis (PCA) irrespectively of starch type or content and fat percent. Pearson's correlation coefficients were determined with the PROC CORR procedure in SAS statistical software v. 9.3 (SAS Institute, Cary). The principal component analysis was performed employing the PROC FACTOR with orthogonal rotation (ROTATE $=$ VARIMAX) to derive noncorrelated factors in the same software.

\section{RESULTS AND DISCUSSION}

\section{Raw and cooked meat batters' properties}

Table 1 shows the results for the raw batters' properties. Water holding capacity was significant $(\mathrm{P}>0.05)$ higher for samples with $10 \%$ of potato starch and $20 \%$ of fat. Total expressible moisture for raw batters was significantly lower $(\mathrm{P}>0.05)$ in formulations containing $10 \%$ of potato starch and $10 \%$ of fat. Cooking stability was significant ( $\mathrm{P}>0.05)$ higher for samples with $10 \%$ of potato starch and $20 \%$ of fat. In the differential scanning calorimetry analysis, samples with $5 \%$ of wheat starch and $10 \%$ of fat presented significant $(\mathrm{P}>0.05)$ higher thermal denaturation temperature values. In the thermal denaturation enthalpy, significant $(\mathrm{P}>0.05)$ higher values were detected in 5\% of wheat starch and $10 \%$ of fat. Thermal diffusivity was significant $(\mathrm{P}>0.05)$ higher in samples with $5 \%$ of potato starch and lower fat content $(10 \%)$.

Table 2 shows the results for the cooked meat batters' results. Cooking yield was significant $(\mathrm{P}>0.05)$ higher in formulation with $10 \%$ of potato starch and $10 \%$ of fat. Sausage samples moisture was significant $(\mathrm{P}>0.05)$ higher in $5 \%$ wheat starch samples containing $10 \%$ of fat. Expressible moisture was significant $(\mathrm{P}>0.05)$ higher in samples with $5 \%$ of wheat starch and $10 \%$ of fat. In the differential scanning calorimetry analysis, samples with $10 \%$ of potato starch with $20 \%$ of fat presented significant $(\mathrm{P}>0.05)$ higher denaturation temperature values. The thermal denaturation enthalpy was significant $(\mathrm{P}>0.05)$ higher values were observed in $10 \%$ of potato starch with $20 \%$ of fat.

In comminuted cooked meat products, there is limited availability of moisture that plays a critical role in determining the microstructure and functional contributions of individual components (Comer et al., 1986). Essentially, in processed meat products the water-binding capacity becomes a critical issue since as the fat content is progressively reduced being compensated with the increase of water content, higher water holding capacity indicated the retaining of more moisture (Pietrasik, 1999). In the same manner, reducing the fat content (up to $80 \%$ ) increased 
Table 1: Raw meat batters' properties for the different fat and starch levels for potato starch or wheat starch

\begin{tabular}{|c|c|c|c|c|c|c|}
\hline \multirow[t]{3}{*}{ Fat (\%) } & \multicolumn{3}{|c|}{ Potato starch (\%) } & \multicolumn{3}{|c|}{ Wheat starch } \\
\hline & 5 & 7.5 & 10 & 5 & 7.5 & 10 \\
\hline & \multicolumn{6}{|c|}{ Batter water holding capacity (\%) } \\
\hline 10 & $61.34 \pm 0.49^{\mathrm{A}, \mathrm{c}, \mathrm{f}}$ & $65.18 \pm 0.34^{\mathrm{A}, \mathrm{b}, \mathrm{f}}$ & $69.55 \pm 0.03^{\mathrm{A}, \mathrm{a}, \mathrm{f}}$ & $62.75 \pm 0.14^{\mathrm{B}, \mathrm{c}, \mathrm{f}}$ & $66.97 \pm 0.51^{\mathrm{B}, \mathrm{b}, \mathrm{f}}$ & $68.99 \pm 0.16^{\mathrm{B}, \mathrm{a}, \mathrm{f}}$ \\
\hline 15 & $69.45 \pm 0.01^{A, c, e}$ & $73.78 \pm 0.74^{\mathrm{A}, \mathrm{b}, \mathrm{e}}$ & $75.80 \pm 0.02^{A, a, e}$ & $69.36 \pm 0.37^{\mathrm{B}, \mathrm{c}, \mathrm{e}}$ & $74.04 \pm 0.18^{\mathrm{B}, \mathrm{b}, \mathrm{e}}$ & $74.00 \pm 0.61^{\mathrm{B}, \mathrm{a}, \mathrm{e}}$ \\
\hline \multirow[t]{2}{*}{20} & $77.51 \pm 0.29^{A, c, d}$ & $79.07 \pm 0.40^{A, b, d}$ & $80.40 \pm 0.09^{A, a, d}$ & $76.42 \pm 0.21^{\mathrm{B}, \mathrm{c}, \mathrm{d}}$ & $79.47 \pm 0.07^{\mathrm{B}, \mathrm{b}, \mathrm{d}}$ & $81.41 \pm 0.47^{\mathrm{B}, \mathrm{a}, \mathrm{d}}$ \\
\hline & \multicolumn{6}{|c|}{ Total expressible fluids(\%) } \\
\hline 10 & $1.47 \pm 0.16^{\mathrm{B}, \mathrm{a}, \mathrm{f}}$ & $2.39 \pm 0.46^{\mathrm{B}, \mathrm{b}, \mathrm{f}}$ & $1.50 \pm 0.07^{\mathrm{B}, \mathrm{c}, \mathrm{f}}$ & $2.05 \pm 0.19^{\mathrm{A}, \mathrm{a}, \mathrm{f}}$ & $0.85 \pm 0.33^{A, b, f}$ & $1.61 \pm 0.05^{\mathrm{A}, \mathrm{c}, \mathrm{f}}$ \\
\hline 15 & $2.54 \pm 0.11^{\mathrm{B}, \mathrm{a}, \mathrm{e}}$ & $0.57 \pm 0.16^{\mathrm{B}, \mathrm{b}, \mathrm{e}}$ & $1.48 \pm 0.12^{\mathrm{B}, \mathrm{c}, \mathrm{e}}$ & $3.41 \pm 0.52^{\mathrm{A}, \mathrm{a}, \mathrm{e}}$ & $2.07 \pm 0.47^{\mathrm{A}, \mathrm{b}, \mathrm{e}}$ & $1.35 \pm 0.22^{A, c, e}$ \\
\hline \multirow[t]{2}{*}{20} & $1.53 \pm 0.31^{\mathrm{B}, \mathrm{a}, \mathrm{d}}$ & $2.08 \pm 0.07^{\mathrm{B}, \mathrm{b}, \mathrm{d}}$ & $1.32 \pm 0.14^{\mathrm{B}, \mathrm{c}, \mathrm{d}}$ & $1.96 \pm 0.18^{\mathrm{A}, \mathrm{a}, \mathrm{d}}$ & $4.10 \pm 0.53^{A, b, d}$ & $2.65 \pm 0.20^{A, c, d}$ \\
\hline & \multicolumn{6}{|c|}{ Cooking stability(\%) } \\
\hline 10 & $97.50 \pm 0.93^{A, c, f}$ & $98.53 \pm 0.91^{\mathrm{A}, \mathrm{b}, \mathrm{f}}$ & $98.47 \pm 0.24^{\mathrm{A}, \mathrm{a}, \mathrm{f}}$ & $94.39 \pm 2.08^{\mathrm{B}, \mathrm{c}, \mathrm{f}}$ & $97.12 \pm 0.10^{\mathrm{B}, \mathrm{b}, \mathrm{f}}$ & $96.41 \pm 2.29^{\mathrm{B}, \mathrm{a}, \mathrm{f}}$ \\
\hline 15 & $97.98 \pm 0.36^{\mathrm{A}, \mathrm{c}, \mathrm{e}}$ & $98.02 \pm 0.10^{A, b, e}$ & $99.61 \pm 0.09^{\mathrm{A}, \mathrm{a}, \mathrm{e}}$ & $97.55 \pm 1.11^{\mathrm{B}, \mathrm{c}, \mathrm{e}}$ & $97.68 \pm 0.42^{\mathrm{B}, \mathrm{b}, \mathrm{e}}$ & $98.85 \pm 0.57^{\mathrm{B}, \mathrm{a}, \mathrm{e}}$ \\
\hline \multirow[t]{2}{*}{20} & $98.65 \pm 0.07^{A, c, d}$ & $98.03 \pm 0.11^{A, b, d}$ & $98.26 \pm 0.17^{\mathrm{A}, \mathrm{a}, \mathrm{d}}$ & $97.95 \pm 0.16^{\mathrm{B}, \mathrm{c}, \mathrm{d}}$ & $98.15 \pm 0.22^{\mathrm{B}, \mathrm{b}, \mathrm{d}}$ & $98.39 \pm 0.06^{\mathrm{B}, \mathrm{a}, \mathrm{d}}$ \\
\hline & \multicolumn{6}{|c|}{ Thermal denaturation temperature $\left({ }^{\circ} \mathrm{C}\right)$} \\
\hline 10 & $101.26 \pm 0.77^{\mathrm{B}, \mathrm{a}, \mathrm{d}}$ & $101.47 \pm 0.27^{\mathrm{B}, \mathrm{b}, \mathrm{d}}$ & $101.84 \pm 1.16^{\mathrm{B}, \mathrm{c}, \mathrm{d}}$ & $107.21 \pm 0.71^{\mathrm{A}, \mathrm{a}, \mathrm{d}}$ & $104.09 \pm 0.59^{\mathrm{A}, \mathrm{b}, \mathrm{d}}$ & $102.15 \pm 0.52^{\mathrm{A}, \mathrm{c}, \mathrm{d}}$ \\
\hline 15 & $102.85 \pm 0.33^{\mathrm{B}, \mathrm{a}, \mathrm{e}}$ & $92.20 \pm 0.22^{\mathrm{B}, \mathrm{b}, \mathrm{e}}$ & $87.23 \pm 1.17^{\mathrm{B}, \mathrm{c}, \mathrm{e}}$ & $101.81 \pm 0.21^{\mathrm{A}, \mathrm{a}, \mathrm{e}}$ & $101.35 \pm 0.53^{\mathrm{A}, \mathrm{b}, \mathrm{e}}$ & $102.17 \pm 0.32^{\mathrm{A}, \mathrm{c}, \mathrm{e}}$ \\
\hline \multirow[t]{2}{*}{20} & $124.64 \pm 1.02^{\mathrm{B}, \mathrm{a}, \mathrm{f}}$ & $103.58 \pm 0.50^{\mathrm{B}, \mathrm{b}, \mathrm{f}}$ & $98.90 \pm 0.78^{B, c, f}$ & $100.15 \pm 0.05^{\mathrm{A}, \mathrm{a}, \mathrm{f}}$ & $100.62 \pm 0.26^{\mathrm{A}, \mathrm{b}, \mathrm{f}}$ & $97.08 \pm 0.10^{A, c, f}$ \\
\hline & \multicolumn{6}{|c|}{ Thermal denaturation enthalpy $\left(\mathrm{J}^{\circ} \mathrm{C}^{-1}\right)$} \\
\hline 10 & $2955.4 \pm 46.7^{\mathrm{B}, \mathrm{a}, \mathrm{d}}$ & $1040.92 \pm 1.12^{\mathrm{B}, \mathrm{b}, \mathrm{d}}$ & $976.49 \pm 4.53^{\mathrm{B}, \mathrm{c}, \mathrm{d}}$ & $2360.9 \pm 1.4^{\mathrm{A}, \mathrm{a}, \mathrm{d}}$ & $136.92 \pm 0.40^{\mathrm{A}, \mathrm{b}, \mathrm{d}}$ & $2726.4 \pm 77.1^{\mathrm{A}, \mathrm{c}, \mathrm{d}}$ \\
\hline 15 & $122.59 \pm 0.64^{\mathrm{B}, \mathrm{a}, \mathrm{e}}$ & $661.20 \pm 0.71^{\mathrm{B}, \mathrm{b}, \mathrm{e}}$ & $51.04 \pm 0.54^{\mathrm{B}, \mathrm{c}, \mathrm{e}}$ & $2351.1 \pm 1.1^{\mathrm{A}, \mathrm{a}, \mathrm{e}}$ & $1405.0 \pm 5.63^{\mathrm{A}, \mathrm{b}, \mathrm{e}}$ & $72.51 \pm 1.10^{\mathrm{A}, \mathrm{c}, \mathrm{e}}$ \\
\hline \multirow[t]{2}{*}{20} & $755.27 \pm 0.50^{\mathrm{B}, \mathrm{a}, \mathrm{f}}$ & $107.18 \pm 0.32^{\mathrm{B}, \mathrm{b}, \mathrm{f}}$ & $31.35 \pm 0.22^{\mathrm{B}, \mathrm{c}, \mathrm{f}}$ & $740.12 \pm 0.45^{\mathrm{A}, \mathrm{a}, \mathrm{f}}$ & $468.16 \pm 1.00^{\mathrm{A}, \mathrm{b}, \mathrm{f}}$ & $58.87 \pm 0.14^{A, C, f}$ \\
\hline & \multicolumn{6}{|c|}{ Thermal diffusivity $\left(\times 10^{7} \mathrm{~m}^{2 \mathrm{~s}-1}\right)$} \\
\hline 10 & $1.616 \pm 0.229^{\mathrm{A}, \mathrm{a}, \mathrm{d}}$ & $1.438 \pm 0.123^{\mathrm{A}, \mathrm{b}, \mathrm{d}}$ & $1.638 \pm 0.008^{A, c, d}$ & $1.385 \pm 0.017^{\mathrm{B}, \mathrm{a}, \mathrm{d}}$ & $1.438 \pm 0.124^{\mathrm{B}, \mathrm{b}, \mathrm{d}}$ & $1.638 \pm 0.008^{\mathrm{B}, \mathrm{c}, \mathrm{d}}$ \\
\hline 15 & $1.600 \pm 0.147^{\mathrm{A}, \mathrm{a}, \mathrm{e}}$ & $1.354 \pm 0.082^{\mathrm{A}, \mathrm{b}, \mathrm{e}}$ & $1.583 \pm 0.034^{\mathrm{A}, \mathrm{c}, \mathrm{e}}$ & $1.469 \pm 0.009^{\mathrm{B}, \mathrm{a}, \mathrm{e}}$ & $1.354 \pm 0.082^{\mathrm{B}, \mathrm{b}, \mathrm{e}}$ & $1.514 \pm 0.039^{\mathrm{B}, \mathrm{c}, \mathrm{e}}$ \\
\hline 20 & $1.515 \pm 0.041^{\mathrm{A}, \mathrm{a}, \mathrm{f}}$ & $1.369 \pm 0.033^{A, b, f}$ & $1.130 \pm 0.009^{A, c, f}$ & $1.552 \pm 0.001^{\mathrm{B}, \mathrm{a}, \mathrm{f}}$ & $1.369 \pm 0.033^{\mathrm{B}, \mathrm{b}, \mathrm{f}}$ & $1.125 \pm 0.002^{\mathrm{B}, \mathrm{c}, \mathrm{f}}$ \\
\hline
\end{tabular}

A, B Means with same letter in same row are not significantly $(P<0.05)$ different for starch type.

$a, b, c$, Means with same letter in same row are not significantly $(P<0.05)$ different for starch percent.

$\mathrm{d}, \mathrm{e}, \mathrm{f}$, Means with same letter in same column are not significantly $(P<0.05)$ different for fat percent.

Table 2: Cooked meat batters' properties for the different fat and starch levels for potato starch or wheat starch

\begin{tabular}{|c|c|c|c|c|c|c|}
\hline \multirow[t]{3}{*}{ Fat (\%) } & \multicolumn{3}{|c|}{ Potato starch (\%) } & \multicolumn{3}{|c|}{ Wheat starch (\%) } \\
\hline & 5 & 7.5 & 10 & 5 & 7.5 & 10 \\
\hline & \multicolumn{6}{|c|}{ Cooking yield $(\%)$} \\
\hline 10 & $118 \pm 1.1^{\mathrm{A}, c, d}$ & $119 \pm 1.0^{A}, b, d$ & $133 \pm 2.1^{\mathrm{A}}, \mathrm{a},{ }^{\mathrm{d}}$ & $110 \pm 1.1_{, c, d}^{B}$ & $121 \pm 1.2^{\mathrm{B}, \mathrm{b}, \mathrm{d}}$ & $119 \pm 1.1^{\mathrm{B}}, \mathrm{a}{ }^{\mathrm{d}}$ \\
\hline 15 & $130 \pm 1.2^{A}, c^{c}, e$ & $130 \pm 1.2^{A}, b^{e}$ & $139 \pm 1.0^{A}, a,{ }^{e}$ & $109 \pm 0.5^{\mathrm{B}, c^{\mathrm{c}}, \mathrm{e}}$ & $120 \pm 1.1^{\mathrm{B}, \mathrm{b}, \mathrm{e}}$ & $116 \pm 1.2^{\mathrm{B}}, \mathrm{a},{ }^{\mathrm{e}}$ \\
\hline \multirow[t]{2}{*}{20} & $126 \pm 0.5^{A}, c, f$ & $130 \pm 1.1_{, A, f}^{A}$ & $120 \pm 0.9^{A}, a,{ }^{\dagger}$ & $113 \pm 1.2^{\mathrm{B}, \mathrm{c}^{\mathrm{C}} \mathrm{f}}$ & $129 \pm 1.0^{\mathrm{B}, \mathrm{b}, \mathrm{f}}$ & $122 \pm 1.1^{\mathrm{B}}, \mathrm{a}{ }^{\mathrm{f}}$ \\
\hline & \multicolumn{6}{|c|}{ Total moisture(\%) } \\
\hline 10 & $65.06 \pm 1.61^{\mathrm{B}, \mathrm{ad}},{ }^{\mathrm{d}}$ & $64.52 \pm 9.29^{\mathrm{B}}, \mathrm{b}, \mathrm{d}$ & $63.31 \pm 4.76^{\mathrm{B}, \mathrm{c}, \mathrm{d}}$ & $66.16 \pm 2.77^{A},{ }^{a},{ }^{d}$ & $62.17 \pm 4.09^{A}, b, d$ & $61.98 \pm 0.26^{A}, c,,^{d}$ \\
\hline 15 & $63.54 \pm 3.50^{\mathrm{B}},{ }^{\text {ae }}$ & $62.79 \pm 6.52^{\mathrm{B}, \mathrm{b}, \mathrm{e}}$ & $62.06 \pm 0.41^{\mathrm{B},{ }^{c},{ }^{e}}$ & $62.56 \pm 2.03^{\mathrm{A}}, \mathrm{a}_{\mathrm{e}}$ & $62.04 \pm 0.36^{A},,_{, e}$ & $60.34 \pm 3.96^{A},{ }^{c}{ }^{e}$ \\
\hline \multirow[t]{2}{*}{20} & $61.25 \pm 5.21^{\mathrm{B}}, \mathrm{a}^{\mathrm{f}}$ & $60.40 \pm 2.48^{\mathrm{B}}, \mathrm{b}, \mathrm{f}$ & $60.11 \pm 2.39^{\mathrm{B},{ }^{\mathrm{c}}, \mathrm{f}}$ & $60.21 \pm 4.66^{A}, a^{\prime}$, & $61.85 \pm 3.11^{A}, b, f$ & $59.63 \pm 0.70^{A}, c^{, f}$ \\
\hline & \multicolumn{6}{|c|}{ Expressible moisture(\%) } \\
\hline 10 & $45.38 \pm 0.24^{\mathrm{B}}, \mathrm{a}^{\mathrm{d}}$ & $33.57 \pm 0.11^{\mathrm{B}, \mathrm{b}, \mathrm{d}}$ & $31.03 \pm 0.14^{\mathrm{B}, c, d}$ & $40.12 \pm 0.39^{A},{ }^{a},{ }^{d}$ & $32.89 \pm 0.11^{A}, b, d$ & $31.03 \pm 1.24^{A}, c^{c d}$ \\
\hline 15 & $38.24 \pm 0.04^{\mathrm{B}, \mathrm{a}, \mathrm{e}}$ & $35.77 \pm 0.10^{\mathrm{B}, \mathrm{b}, \mathrm{e}}$ & $29.65 \pm 1.03^{B},{ }^{c},{ }^{e}$ & $37.77 \pm 0.01^{\mathrm{A}}, \mathrm{a}_{\mathrm{e}}$ & $32.75 \pm 0.12^{A}, b_{,}^{e}$ & $30.09 \pm 0.09^{A},{ }^{c}, e$ \\
\hline \multirow[t]{2}{*}{20} & $33.97 \pm 0.36^{\mathrm{B}}, \mathrm{a}, \mathrm{f}$ & $31.42 \pm 0.01^{\mathrm{B}, \mathrm{b}, \mathrm{f}}$ & $27.55 \pm 0.02^{\mathrm{B}}, \mathrm{c}, \mathrm{f}$ & $33.05 \pm 0.03^{A}, a^{f}$ & $31.19 \pm 0.43^{A}, b$, & $25.38 \pm 0.05^{A},{ }^{c},{ }^{f}$ \\
\hline & \multicolumn{6}{|c|}{ Thermal denaturation temperature $\left({ }^{\circ} \mathrm{C}\right)$} \\
\hline 10 & $109.28 \pm 0.36^{A},{ }^{c, d}$ & $108.80 \pm 0.21^{A}, b,{ }^{d}$ & $107.29 \pm 0.44^{\mathrm{A}},{ }^{a},{ }^{d}$ & $104.38 \pm 0.29^{B},{ }_{c}^{d}$ & $108.47 \pm 0.48^{\mathrm{B}, \mathrm{b}, \mathrm{d}}$ & $109.12 \pm 0.39^{\mathrm{B}},{ }^{\mathrm{a}},{ }^{\mathrm{d}}$ \\
\hline 15 & $107.93 \pm 0.17^{A}, c^{c e}$ & $105.76 \pm 0.26^{A}, b, e$ & $110.91 \pm 0.10^{\mathrm{A}}, \mathrm{a}, \mathrm{e}$ & $102.85 \pm 0.11^{\mathrm{B}, \mathrm{c}, \mathrm{e}}$ & $105.93 \pm 0.27^{\mathrm{B}, \mathrm{b}, \mathrm{e}}$ & $112.30 \pm 0.43^{\mathrm{B}}, \mathrm{a}^{\mathrm{e}}$ \\
\hline \multirow[t]{2}{*}{20} & $104.18 \pm 0.20^{A}, c^{f}$, & $108.39 \pm 0.53^{A}, b$, & $111.04 \pm 0.05^{\mathrm{A}},{ }^{\mathrm{a}} \mathrm{f}$ & $101.80 \pm 0.07^{B}, c, f$ & $106.08 \pm 0.11^{\mathrm{B}}, \mathrm{b}, \mathrm{f}$ & $105.36 \pm 0.48^{\mathrm{B}, \mathrm{a}, \mathrm{f}}$ \\
\hline & \multicolumn{6}{|c|}{ Thermal denaturation enthalpy $\left(\mathrm{J} /{ }^{\circ} \mathrm{C}\right)$} \\
\hline 10 & $2683.1 \pm 0.14^{\mathrm{A}}, \mathrm{c}, \mathrm{f}$ & $2546.2 \pm 1.99^{\mathrm{A}}, \mathrm{b}, \mathrm{f}$ & $2808.5 \pm 2.91^{\mathrm{A}},{ }_{,}^{f}$ & $2389.3 \pm 1.57^{\mathrm{B}, \mathrm{c}, \mathrm{f}}$ & $2430.6 \pm 4.73^{\mathrm{B}}, \mathrm{b}, \mathrm{f}$ & $2645.6 \pm 1.01^{\mathrm{B}, \mathrm{a}, \mathrm{f}}$ \\
\hline 15 & $2459.7 \pm 0.28^{A},{ }^{c},{ }^{e}$ & $2608.9 \pm 7.63^{A}, b_{,}$, & $2668.2 \pm 0.43^{\mathrm{A}}, \mathrm{a}, \mathrm{e}$ & $2747.8 \pm 40.1^{\mathrm{B}}, \mathrm{c}^{\mathrm{ce}}$ & $2230.3 \pm 4.11^{\mathrm{B}, \mathrm{b}, \mathrm{e}}$ & $2765.3 \pm 0.99^{\mathrm{B}}, \mathrm{a}_{\mathrm{e}}$, \\
\hline 20 & $2777.0 \pm 1.50^{A},{ }^{c},{ }^{d}$ & $2324.9 \pm 533^{A}, b, d$ & $2973.5 \pm 7.15^{\mathrm{A}},{ }^{\mathrm{a}, \mathrm{d}}$ & $2623.9 \pm 25.8^{\mathrm{B}, \mathrm{c}, \mathrm{d}}$ & $2906.7 \pm 5.24^{B}, b, d$ & $2767.2 \pm 2.99^{\mathrm{B}}, \mathrm{a}^{\mathrm{d}}$ \\
\hline
\end{tabular}

\footnotetext{
A, B Means with same letter in same row are not significantly $(\mathrm{P}<0.05)$ different for starch type.

$a, b, c$, Means with same letter in same row are not significantly $(P<0.05)$ different for starch percent.

$d, e, f$, Means with same letter in same column are not significantly $(P<0.05)$ different for fat percent.
} 
cook loss and decreased both water-holding capacity and emulsion stability (Hughes et al., 1996). The effect of starches in comminuted meat products has been proved pragmatically and empirically. The greater the fat content, the smaller the weight loss, due to the less moisture, and thus, the more starch added, the less weight was lost during cooking (Pietrasik, 1999). An increase in the starch level decreased cooking loss when the fat content was reduced, since hydrated starch gelatinized during cooking, increasing emulsion viscosity and lower fat globule mobility binding more water (Bañon et al., 2008).

During the processing of comminuted meat products, the hydrated starch granules are responsible to retain the remain free water in the meat batter formulation, until cook when due to the permeable casing film starch granules can finish absorbing water. Differential scanning calorimetry showed differences between raw and cooked samples since wheat starch containing samples required more energy (higher peak $\mathrm{Td}$ and $\Delta \mathrm{H}$ ) in the raw state, but after cook, the potato starch samples presented both higher peak thermal denaturation temperature and enthalpy. Nonetheless, when raw meat batters were subject to thermal processing, there were changes in the meat batters, components, starting with the starch granules hydration during mixing and before the internal core temperature reached the respective gelatinization temperature ( $\mathrm{Li}$ and Yeh, 2002, 2003). The differences in transition temperatures between the different starches may be attributed to the differences in the degree of crystallinity and water absorption capacity. Potato starch had both higher thermal denaturation temperature peak $\left(62.9^{\circ} \mathrm{C}\right)$ and denaturation enthalpy $(17.4 \mathrm{~J} 7 \mathrm{~g})$, as compared to wheat starch $\left(52.2^{\circ} \mathrm{C}\right.$ and $14.8 \mathrm{~J} / \mathrm{g}$ ) (Singh et al., 2003), besides a higher amount of amylopectin and a higher degree of polymerization (79 and 72 of amylose content, 3000 and 800 of the degree of polymerization, respectively) (Swinkles, 1985). This is why potato starch, with the lowest gelatinization temperature, and after being cooked at $56{ }^{\circ} \mathrm{C}$ was embedded in the meat proteins matrix, but not closely contacted with the protein matrix network (Li and Yeh, 2002). This is the same reason why thermal diffusivity was higher in samples containing less amount of both potato starch and fat, with higher moisture content. Thermal diffusivity in emulsion-type sausages affected by fat and moisture content. On one hand, the effect of moisture on thermal diffusivity decrease as cooking progresses, since when the temperature reaches $60^{\circ} \mathrm{C}$, most of the muscle proteins are denatures (within the $40-5^{\circ} \mathrm{C}$ range), with a sharp decrease in the water holding capacity. On the other hand, fat content affects thermal diffusivity by the phase change over two ranges of temperature where fat is predominantly in a solid phase $\left(26-33^{\circ} \mathrm{C}\right)$ and when it is in a predominantly liquid phase $\left(34-40^{\circ} \mathrm{C}\right.$ ) (Mittal et al., 1989). With potato starch retaining more water at low-fat content, higher diffusion of the heat throughout meat batters was observed.

\section{Correlation and principal components analysis}

Table 3 shows Pearson's correlation coefficients and significance of the analyzed variables. In raw batters' properties, the was a highly significant $(\mathrm{P}>0.01)$ inverse correlation between raw total expressible moisture and water holding capacity. Raw meat batters' denaturation enthalpy presented a highly significant $(\mathrm{P}>0.01)$ inverse correlation with batter water holding capacity, and a significant $(\mathrm{P}>0.05)$ correlation with both cook stability (inverse) and total expressible moisture. Thermal diffusivity was highly significant $(\mathrm{P}>0.01)$ correlated with raw batter denaturation enthalpy and presented as well a significant $(\mathrm{P}>0.05)$ correlation with water holding capacity (negative) and total expressible moisture (positive). This means that the higher the water holding capacity of raw batters the lower total expressible moisture, due to the inability to retain water by the formulation with higher starch and higher fat content (less moisture remaining). In the same manner, lower water holding capacity was related to lower heat denaturation enthalpy. And high denaturation enthalpy of raw meat batters corresponded to higher thermal diffusivity values. This is, higher solids content required more heat to be thermally denatured.

In the cooked batters' properties, there was an intrinsic highly significant $(\mathrm{P}>0.01)$ correlation among moisture with cooking yield (positive), expressible moisture (negative), denaturation temperature (positive), and denaturation enthalpy (negative). In the same manner, cooking yield presented as well a highly significant $(\mathrm{P}>0.01)$ correlation with expressible moisture (inverse) and denaturation temperature (direct). Expressible moisture presented a highly significant $(\mathrm{P}>0.01)$ inverse correlation with denaturation temperature and a significant $(\mathrm{P}>0.05)$ correlation with denaturation enthalpy. This means that total moisture was related to high cook yield and both lower water-released (expressible moisture) and lower denaturation enthalpy since most of the components in the formulation were already denatured during thermal processing. When water cannot be physically retained in the meat system, low moisture and cooking yield were obtained, with a concomitantly lower denaturation temperature as well, probably by less water available after cook.

The correlation between cooked meat batters and raw meat batters was as follows. Cooked meat batters' moisture presented a highly significant $(\mathrm{P}>0.01)$ correlation with all the raw meat batters' properties, positive with cook stability and water holding capacity, and inverse with total expressible moisture, both denaturation temperature, and enthalpy, and thermal diffusivity. The cooking yield 


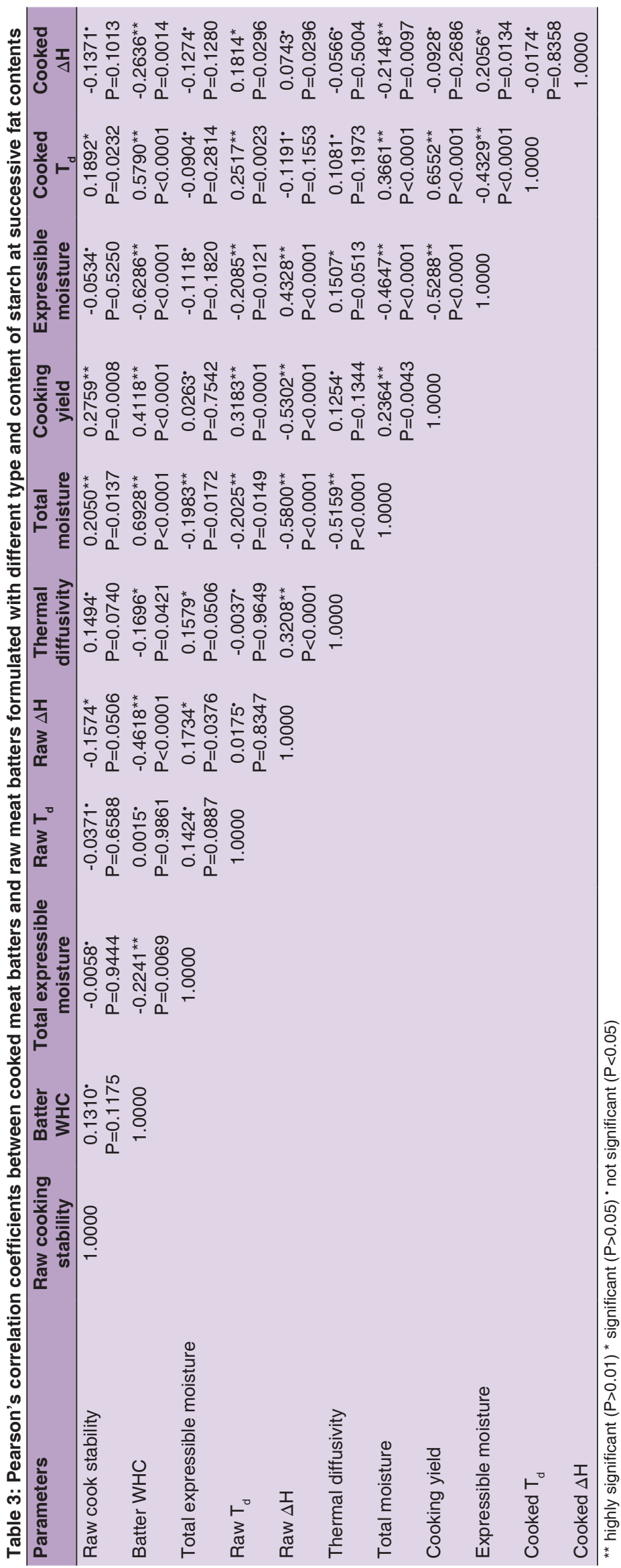


had a highly significant $(\mathrm{P}>0.01)$ correlation with cook stability, water holding capacity, denaturation temperature, and denaturation enthalpy (inverse with this one). For expressible moisture, there was a correlation only with both denaturation temperature (inverse) and denaturation enthalpy, and a significant $(\mathrm{P}>0.05)$ direct correlation with thermal diffusivity. Cooked denaturation temperature was significant $(\mathrm{P}>0.05)$ correlated with raw cooking stability, and highly significant $(\mathrm{P}>0.01)$ correlated directly with both the raw water holding capacity and the raw denaturation temperature. Finally, cooked meat batters' denaturation temperature presented a highly significant $(\mathrm{P}>0.01)$ inverse correlation with raw water holding capacity, and a significant $(\mathrm{P}>0.05)$ direct correlation with raw denaturation temperature (Table 3). In raw meat batters, when the proteinstarch matrix releases more water, the total expressible moisture decreased since the amount of available water for protein to emulsify or starch to swell was lower. During thermal treatment, if raw meat batters retain more water, the energy (enthalpy) during this process decrease since proteins and starches solubility or the competition for free water is lower. This was also observed between total expressible moisture and denaturation enthalpy, where less released fat (emulsified) corresponds to higher energy required during cooking since both proteins and starches are occupied stabilizing the emulsion. During this process, if water retention decreased, the thermal diffusivity increased; and if fat was retained in the protein-starch matrix, thermal diffusivity increased. If higher energy applied during heating, as denaturation enthalpy, was detected during heating, the thermal diffusivity was higher as well. In cooked batters, the system became more stable after thermal processing where proteins formed the tridimensional meat batter matrix, and starches swell and retain the available free water.

Since a significant correlation was found among most of the investigated variables, the principal components analysis was performed. In the initial factor method of analysis of principal components, the eigenvalues revealed that two components presented a good summary of analyzed data, with $81.72 \%$ of the total variance (factor $1=$ $32.70 \%$, and factor $2=49.02 \%$ ). PCA was performed to determine the relationship among the parameters related to raw and cooked meat batters, and their distribution into two dimensions space. Factor 1 was positively correlated with raw cooking stability, batter water holding capacity, raw denaturation temperature, total moisture, cooking yield, and cooked denaturation temperature; and was negatively correlated with raw total expressible moisture, raw denaturation temperature, thermal diffusivity, expressible moisture, and cooked denaturation temperature. Factor 2 was correlated with raw thermal denaturation temperature, total expressible moisture, raw denaturation temperature, raw denaturation enthalpy, cooking yield, cooed denaturation temperature, and cooked denaturation enthalpy; and with an inverse correlation with batter water holding capacity, total moisture, and expressible moisture. Final communalities showed that were well accounted for the two factors (estimates from 0.5612 to 0.8414 ) (Table 4).

There is two important aspect in the type starch application in comminuted meat products, where although the type of starch is important, the thermal processing under comminuted meat batters conditions defines the functional behavior of the starches in cooked meat products, with an inherent effect due to starch and/or fat concentration. First, the role of meat extenders is to improve yield and enhance texture in meat products. Historically, wheat flour and later wheat starch was employed as the most common extenders, until the use of other starches with different functionality, like potato starch or modified starches. Filled gels are those in which one macromolecule forming the main gel matrix while the other macromolecules are acting as fillers in a secondary gel network or as an insoluble polymeric material, in this view, the addition of fillers such as starch will change rheological properties and water-holding capacity (Shand, 1999). During the cooking process, the solubilized protein and insoluble carbohydrate components in the meat system set up to contribute to gel structure formation, into a stable, structured, and homogeneous system, where the filler and meat ingredients differences are related to the differences in gelation properties (Comer, 1989). When the mixed food including starch is heated, a competition between gelation processes takes place with varying levels of competition to establish gel structure which will lead to the creation of several varieties of gel structures with different structural properties (Jamilah et al., 2009).

Second, and more important, is the behavior of the starch as fillers before, during, and after meat batters' thermal processing, moreover when more moisture is available in fat-reduced meat emulsions. Meat batter temperature

\begin{tabular}{|c|c|c|c|}
\hline \multirow[t]{2}{*}{ Parameter } & \multicolumn{2}{|c|}{$\begin{array}{l}\text { Rotated factor } \\
\text { pattern }\end{array}$} & \multirow{2}{*}{$\begin{array}{c}\text { Final communality } \\
\text { estimates } \\
\text { (Total }=7.83 \text { ) }\end{array}$} \\
\hline & Factor1 & Factor2 & \\
\hline Raw cooking stability & 0.28314 & 0.18168 & 0.7503 \\
\hline Batter WHC & 0.85080 & -0.10228 & 0.7392 \\
\hline Raw emulsion stability & -0.16022 & 0.41976 & 0.7504 \\
\hline Raw Td & 0.11815 & 0.59373 & 0.7119 \\
\hline Raw $\Delta \mathrm{H}$ & -0.69499 & 0.25926 & 0.5612 \\
\hline Thermal diffusivity & -0.26592 & 0.65982 & 0.7653 \\
\hline Total moisture & 0.77655 & -0.48375 & 0.8414 \\
\hline Cooking yield & 0.71315 & 0.51063 & 0.7816 \\
\hline Expressible moisture & -0.76107 & -0.16020 & 0.7403 \\
\hline Cooked Td & 0.66621 & 0.44304 & 0.7125 \\
\hline Cooked $\Delta \mathrm{H}$ & -0.25378 & 0.06793 & 0.7128 \\
\hline
\end{tabular}




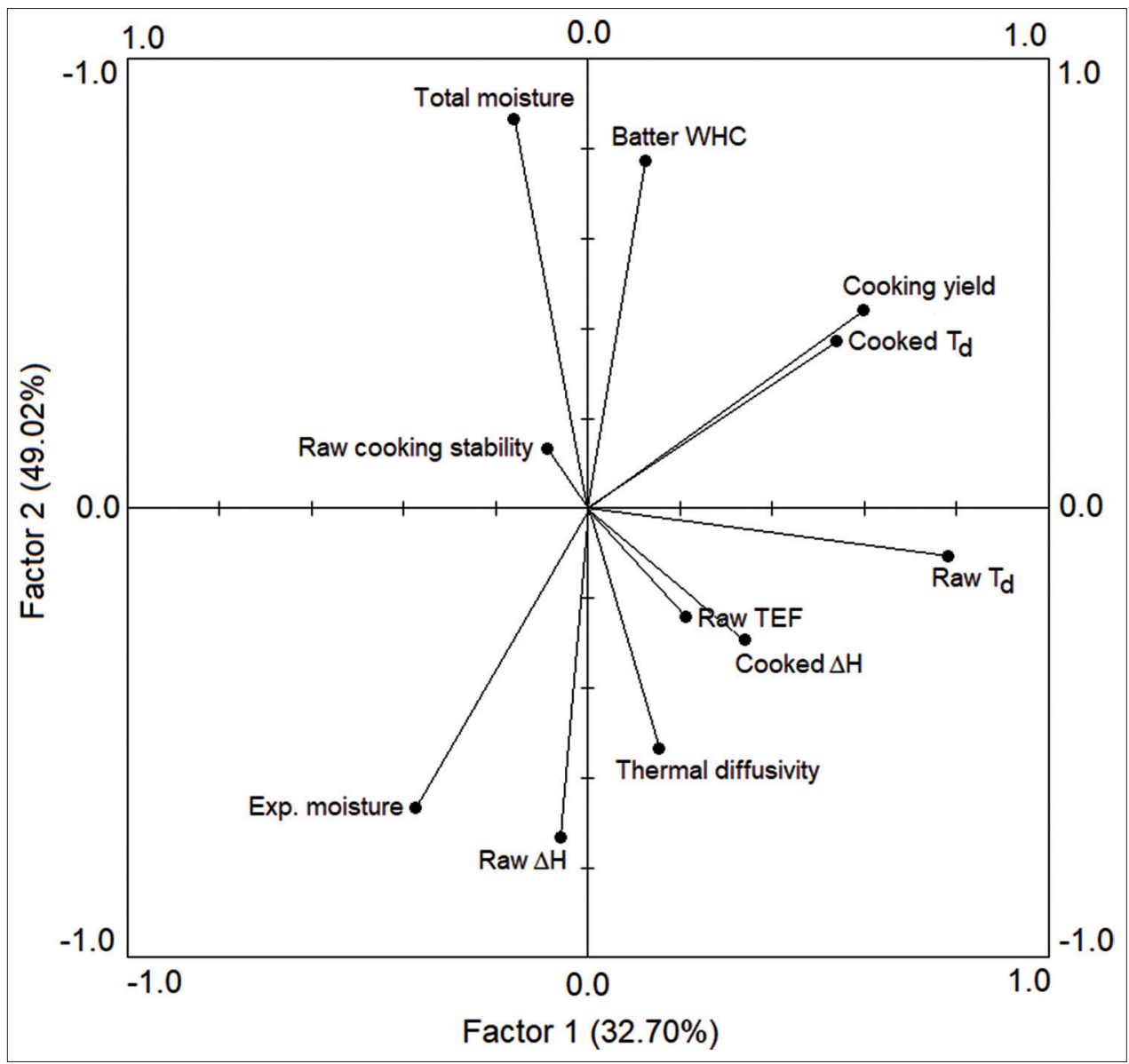

Fig 1. Bi-plot curve of principal component 1 versus principal component 2 for the raw and cooked meat batters' variables.

must be between $8-12{ }^{\circ} \mathrm{C}$ to maintain the functionality of myofibrillar proteins before activation or solubilization by the added salt and phosphates mixture into the formulation. Solubilized proteins can then emulsify fat before heat gelation. Starch is added after fat when the moisture in the meat batter is relatively low due to the high viscosity of the solubilized myofibrillar proteins matrix.

The nature of the fillers is reflected in the cold and hot water absorption, where potato starch granules absorb a large amount of moisture at $70{ }^{\circ} \mathrm{C}$ but a low cold absorption (Comer, 1989). The basic structure of the food gels with starch is established during heating, where components gelation and phase separation takes place until gelation occurs (Owens and Jones, 1998; Elgadir et al., 2009). But the gelatinization temperatures refer to dilute aqueous solutions of starches heated under specified conditions and may not accurately indicate the temperatures of gelatinization when the starches are used in complex systems like sausages since several factors influence the behavior of starch upon heating (Skrede, 1989). Throughout the meat batters thermal processing, meat proteins gelation and interaction started at $45-50{ }^{\circ} \mathrm{C}$ in the myosin gel formation, and heating at $50-60{ }^{\circ} \mathrm{C}$ allows the formation of a larger globular proteins aggregate
(Tornberg, 2005). This is, meat protein started denaturation before starch gelatinization ( $\mathrm{Li}$ and Yeh, 2002). For starches, although the gelatinization temperature range is $60-65^{\circ} \mathrm{C}$ for potato starch and $80-85^{\circ} \mathrm{C}$ for wheat starch (Skrede, 1989), the added $\mathrm{NaCl}$ to increase ionic strength and solubilize myofibrillar proteins repressed the swelling of starch granules (Bello-Pérez and Paredes-López, 1995), increasing the gelatinization temperature ( $\mathrm{Li}$ and Yeh, 202; Elgadir et al., 2009). Nonetheless, in comminuted meat products, the contribution of starch as fillers does not imply the formation of a starch matrix, since fillers are scattered with fat globules, best described as a mechanical mixture (Comer et al., 1986). Employing the same formulations, Toledo (2019) reported that sausages with $10 \%$ of potato starch and lower fat content were softer and more cohesive, with higher springiness and resilience values as well than samples with the same amount of wheat starch, due to the formation of a more dense and compact meat batter matrix with lower available moisture (water provide softness but not springiness), in a sort of competence between ingredients for water.

In the biplot graph, the higher water holding capacity of the raw batter resulted as well in higher cooked denaturation temperature and cooking yield. In contrast, lower denaturation 
enthalpy was related to higher expressible moisture (Fig. 1). The main factors involved in cooked comminuted meat products are the raw denaturation enthalpy or energy necessary for both protein gelation and starch gelatinization, and the water holding capacity, as a mean to obtain a higher cook yield that releases less moisture in the final product.

\section{CONCLUSION}

Since starches are the most commonly employed meat products extender, influencing the moisture properties of this kind of emulsified products, to determine their functionality before and after thermal processing is important in order to obtain a standard product with high quality, moreover in fat-reduced meat products. Although of the lower gelatinization temperature of potato starch that retained more water, the use of any kind of starch must follow the finding in this research, where raw batters properties that had a major effect on final moisture were the water holding capacity and the energy absorbed during thermal processing to proteins and starch gelification and gelatinization, respectively. Both properties resulted in higher cook yield resulting from lower expressible moisture, moreover when more moisture is available in fat-reduced meat batters, establishing the importance of the relationship between both thermal and emulsion meat batter stability during ingredients mixing (in the cold) before thermal processing (heat denaturation).

\section{ACKNOWLEDGMENTS}

Octavio Toledo thanks to Consejo Nacional de Ciencia y Tecnología (CONACYT) the grant for his graduate studies (Padrón Nacional de Posgrado de Posgrado No. Ref. 1665-0).

\section{REFERENCES}

Aktas, N. and H. Gençelep. 2006. Effect of starch type and its modifications on physicochemical properties of bologna-type sausage produced with sheep tail fat. Meat Sci. 74: 404-408.

AOAC. 1999. Official Method 950.46: Moisture in Meat. Official Methods of Analysis of AOAC International. $16^{\text {th }}$ ed. AOAC International, Washington, DC.

Bañón, S., P. Díaz, G. Nieto, M. Castillo and D. Álvarez. 2008. Modelling the yield and texture of comminuted pork products using color and temperature. Effect of fat/lean ratio and starch. Meat Sci. 80: 649-655.

Bello-Pérez, L. A. and O. Paredes-López. 1995. Starch and amylopectin: Effect of solutes on their calorimetric behavior. Food Chem. 53: 243-247.

Comer, F. W., N. Chew, L. Lovelock and P. Allan-Wojtas. 1986. Comminuted meat products: Functional and microstructural effects of fillers and meat ingredients. Can. Inst. Food Sci. Technol. J. 19: 68・74.

Comer, F. W. 1989. Functionality of fillers in comminuted meat products. Can. Inst. Food Sci. Technol. J. 12: 157-165.

Der, G. and B. S. Everitt. 2008. A Handbook of Statistical Analyses Using SAS. 3rd ed. Chapman and Hall/CRC, London, pp. 99-109.

Dexter, D. R., J. N. Sofos and G. R. Schmidt. 1993. Quality characteristics of Turkey bologna formulated with carrageenan, starch, milk and soy protein. J. Muscle Foods. 4: 207-223.

Elgadir, M. A., J. Bakar, I. S. M. Zaidul, R. A. Rahman, K. A. Abbas, D. M. Hashim and R. Karim. 2009. Thermal behavior of selected starches in presence of other food ingredients studied by differential scanning calorimetery (DSC)-review. Comp. Rev. Food. Sci. Food. Saf. 8: 195-201.

Haq, A., N. B. Webb, J. K. Whitfield and G. S. Morrison. 1972. Development of prototype sausage emulsion preparation system. J. Food Sci. 37: 480-484.

Hughes, E., D. J. Troy and S. Cofrades. 1996. Effects of fat level, oat fibre and carrageenan on frankfurters formulated with 5, 12 and 30\% fat. Meat Sci. 45: 273-281.

Jamilah, B., A. Mohamed, K. A. Abbas, R. A. Rahman, R. Karim and D. M. Hashim. 2009. Protein-starch interaction and their effect on thermal and rheological characteristics of a food system: A review. J. Food Agric. Environ. 7: 169-174.

Jauregui, C. A., J. M. Regenstein and R. C. Baker. 1981. A simple centrifugal for measuring expressible moisture, a water-binding property of muscle foods. J. Food Sci. 46: 1271-1273.

Joly, G. and B. Anderstein. 2009. Starches. In: R. Tartré (Ed.), Ingredients in Meat Products. Springer Science + Business Media, LLC, New York, pp. 925-956.

Li, J. Y. and A. I. Yeh. 2002. Functions of starch in formation of starch/ meat composite during heating. J. Texture Stud. 33: 341-366.

Li, J. Y. and A. I. Yeh. 2003. Effects of starch properties on rheological characteristics of starch/meat complexes. J. Food Eng. 57: 287-294.

Markowski, M., I. Bailobrzewski, M. Cierach and A. Paulo. 2004. Determination of thermal diffusivity of Lyoner type sausages during water bath cooking and cooling. J. Food Eng. 65: 591-598.

Mittal, G. S., C. Y. Wang and W. R. Usborne. 1989. Thermal properties of emulsion type sausages during cooking. Can. Inst. Food Sci. Technol. 22: 359-363.

Owens, A. J. and R. A. L. Jones. 1998. Rheology of simultaneously phase separating and gelling biopolymer mixture. J. Macromol. 3: 7336-7339.

Pietrasik, Z. 1999. Effect of content of protein, fat and modified starch on binding textural characteristics, and colour of comminuted scalded sausages. Meat Sci. 51: 17-25.

Shand, P. J. 2000. Textural, water holding, and sensory properties of low-fat pork bologna with normal o waxy starch hull-less barley. J. Food Sci. 65: 101-107.

Shand, P. J. 1999. Water immobilization in low-fat meat batters. In: Y. L. Xiong, C. T. Ho and F. Shahidi (Eds.), Quality Attributes of Muscle Foods. Ch. 23. Springer Science + Business Media, LLC, New York, pp. 335-352.

Singh, N., J. Singh, L. Kaur, N. S. Sodhi and B. S. Gill. 2003. Morphological, thermal and rheological properties of starches from different botanical sources. Food Chem. 81: 219-231.

Skrede, G. 1989. Comparison of various types of starch when used in meat sausages. Meat Sci. 25: 21-36.

Swinkels, J. J. M. 1985. Composition and properties of commercial native starches. Starch. 37: 1-5.

Toledo, O. 2019. Starch percent and type (potato or wheat) affects fat reduced meat batters instrumental texture. Nacameh. 13: 1-10.

Tornberg, E. 2005. Effects of heat on meat proteins implications on structure and quality of meat products. Meat Sci. 70: 493-508. 